\title{
General image of tourist destination of Nepal from tourist perspective
}

\author{
Amrit Kumar Gurung ${ }^{1}$ \\ ${ }^{1}$ Ph.D Scholar, Mewar University \\ Gangrar, Chittorgar Rajasthan India \\ amrityug10@yahoo.com
}

\begin{abstract}
Background and objective: Tourists are the people who visit new places to observe the places, natural beauty, cultural-environment, and many more rituals. The study was conducted to explore the general image of tourist destination of Nepal from the tourist perspective. Methodology: The study was conducted in the tourist destination of Kathmandu valley when tourists of different countries were randomly selected. The study was based on the descriptive research design. Structured questionnaires were developed using Likert's scale. Result: There was no significant association found between the perceptions of tourists in tourist destination of Nepal. Around 38\% had neutral answer about the availability of tourist police in tourist destination as well as more than $45 \%$ had neutral answer about the effectiveness of tourist police in promoting safe tourism. Conclusion: Natural beauty of tourist destination should be safe and the environment should be cleaned. There is a necessity to increase the numbers of tourist police for the promotion of safe tourism.
\end{abstract}

KEYWORDS: Destination, perception, safety, tourist

\section{INTRODUCTION}

Since opening the country to the outsiders in 1950, Nepal has acquired identity as a popular tourist destination and the number of tourists coming into the country has constantly increased. The United Nations Conference on International Travel and Tourism (Rome, 1963) recommended a definition for the terms "visitor", "tourist" and "excursionist" proposed by IUOTO (WTO, 1995, p. 1). Particularly for the leisure tourist, it is a voluntary activity undertaken by choice (Cohen, 2004); a discretionary work (Beirman, 2003, p. 3). The temporary visitor staying in a place outside their usual place of residence, for a continuous period of at least 24 hours but less than one year, for leisure, business or other purpose (World Tourism Organization, 1993).

In recent times, tourism research has begun to engage with theoretical issues more explicitly to explore the unexplored areas of tourism issues in fast the changing global economy. In the context of tourism marketing, the image tourists have of tourist destination is an element of major importance (Tasci, 2007). A tourist destination can be defined as a geographical area that is perceived as a separate unit by tourists (Kuscer, 2012, p. 7). The selection of tourist destination "is not a simple decision because selection is derived from a set of independent choices." (Garcia, 2012, p. 65). The image of tourist destination is strongly connected to the image of the country, image of the nation and the image of place. "...Image is one of those terms that will not go away... a term with vague and shifting meanings (Pearce, 1988, p. 162)". In tourism, a brand image is a mental representation that always evokes in the customer's mind (Rahaman, 2012, p. 84) the unique history, heritage and culture of a particular destination (Henkinson, 2004). According to Lawson and Bovy (1997), image destination is defined as "an expression of knowledge, impressions, prejudices, imaginations and emotional thoughts for the general image of a destination, some authors suggest that these two (cognitive and affective) components determine whether that general image will be a positive or negative assessment of the destination (Blsuglu \& McCleary, 1999a). 


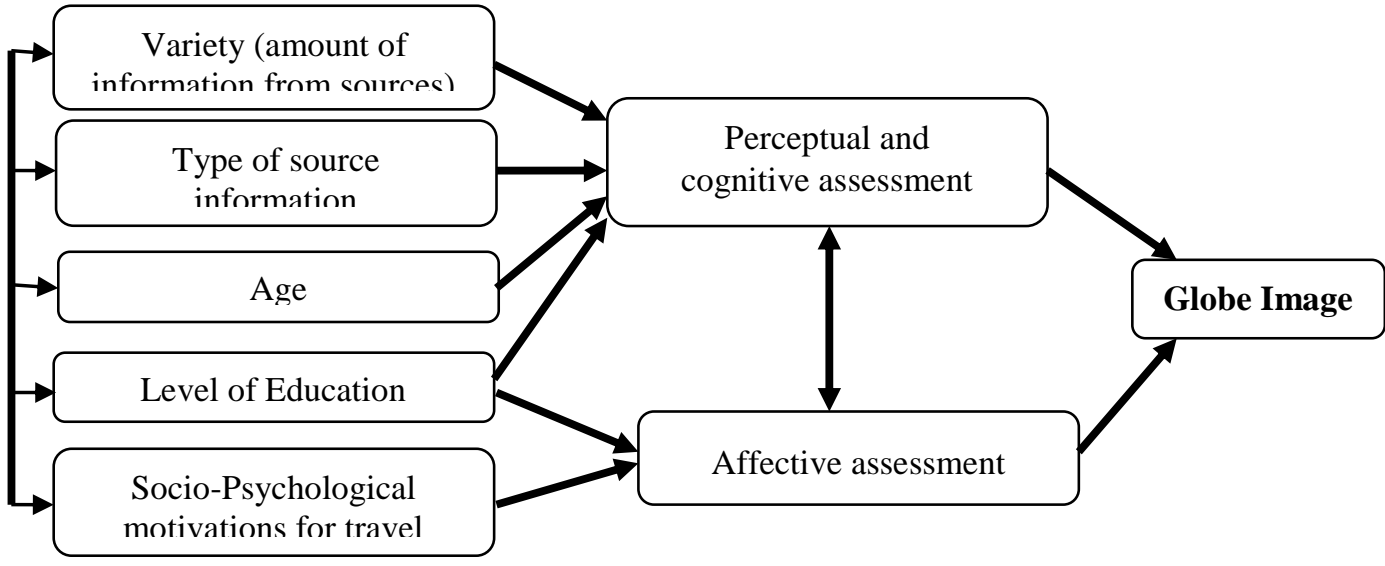

Figure1.Path model of determinants of the destination of image

(Baloglu and Mackcleary 1999a)

Cognitive image refers to beliefs, impressions, ideas, perceptions and knowledge that people hold about an object (Crompton, 1979) and affective image is about how a person feels about the object (Rajesh, 2013, p. 68). The influence of push and pull factors on the way tourists perceive the destination give an idea about why tourists adopt specific behaviour (Hemant \& Rhaaita, 2013, p. 2). Most push factors are intrinsic motivators, such as the desire for escape, rest and relaxation, prestige, health and fitness, adventure and social interaction whereas pull factors emerge from to the attractiveness of a destination, including beaches, recreation facilities and cultural attractions (Woodside \& Martin, 2008, p. 18).

There are various theories related with the image of tourist destination. Among them, stagetheory is one which explained about the stage of image. The stages of image compare the images before and after travel. The stages are as below figure 3 .

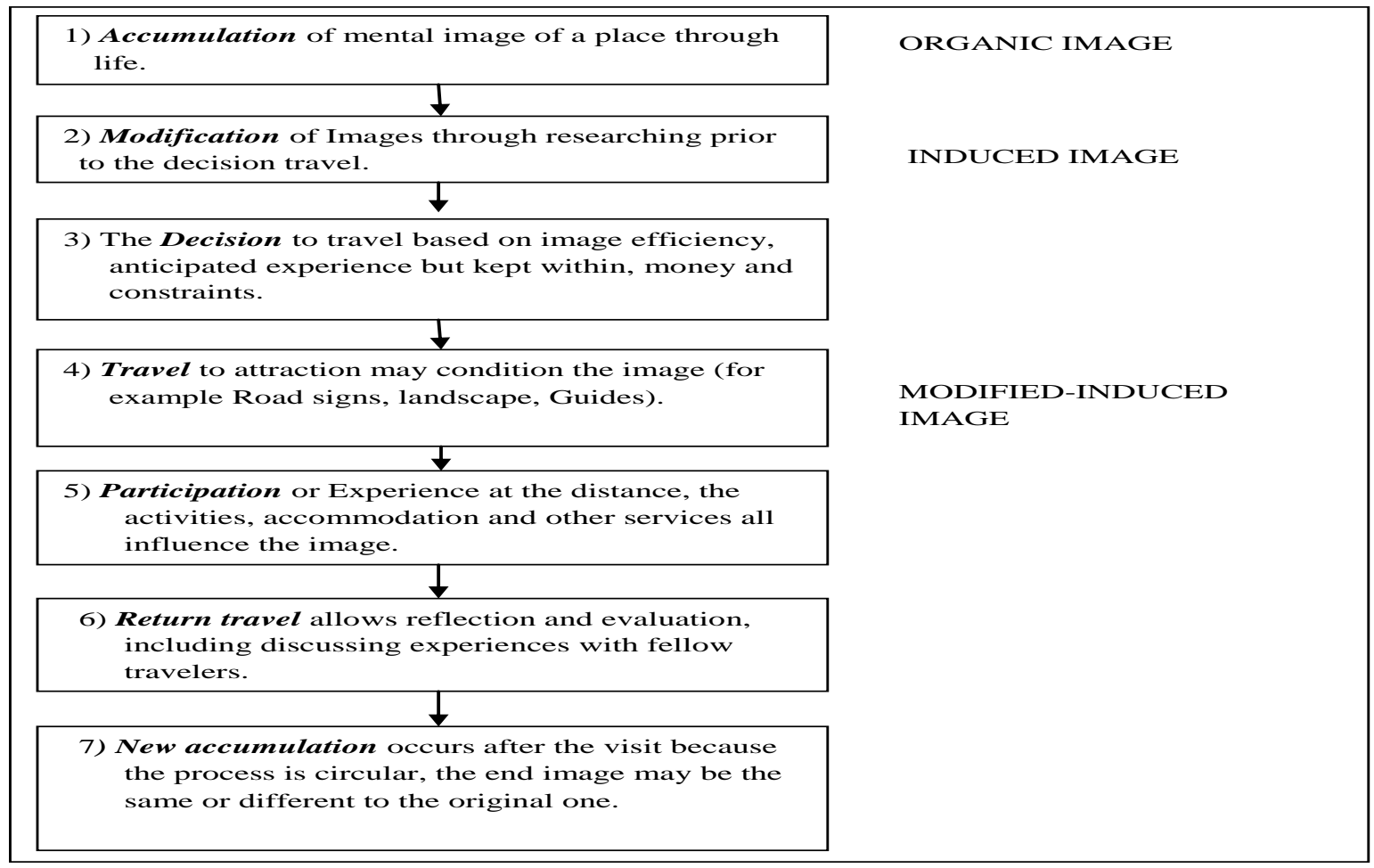

Figure 3.Stage-theories of destination image (Gunn, 1972, p. 120). 
The stage theory explains that the images will differ: by potential visitors, non-visitors and returned visitors' have different images. The image of Nepal as a travel destination is not only based on the perception, ratings of various functional and psychological attributes but also on the more holistic mental pictures, or imageries evoked (Etchner \& Ritchie 2003, p. 43). The image of Nepal is explained through the following figure 4.

\section{Functional}

\section{Characteristics}

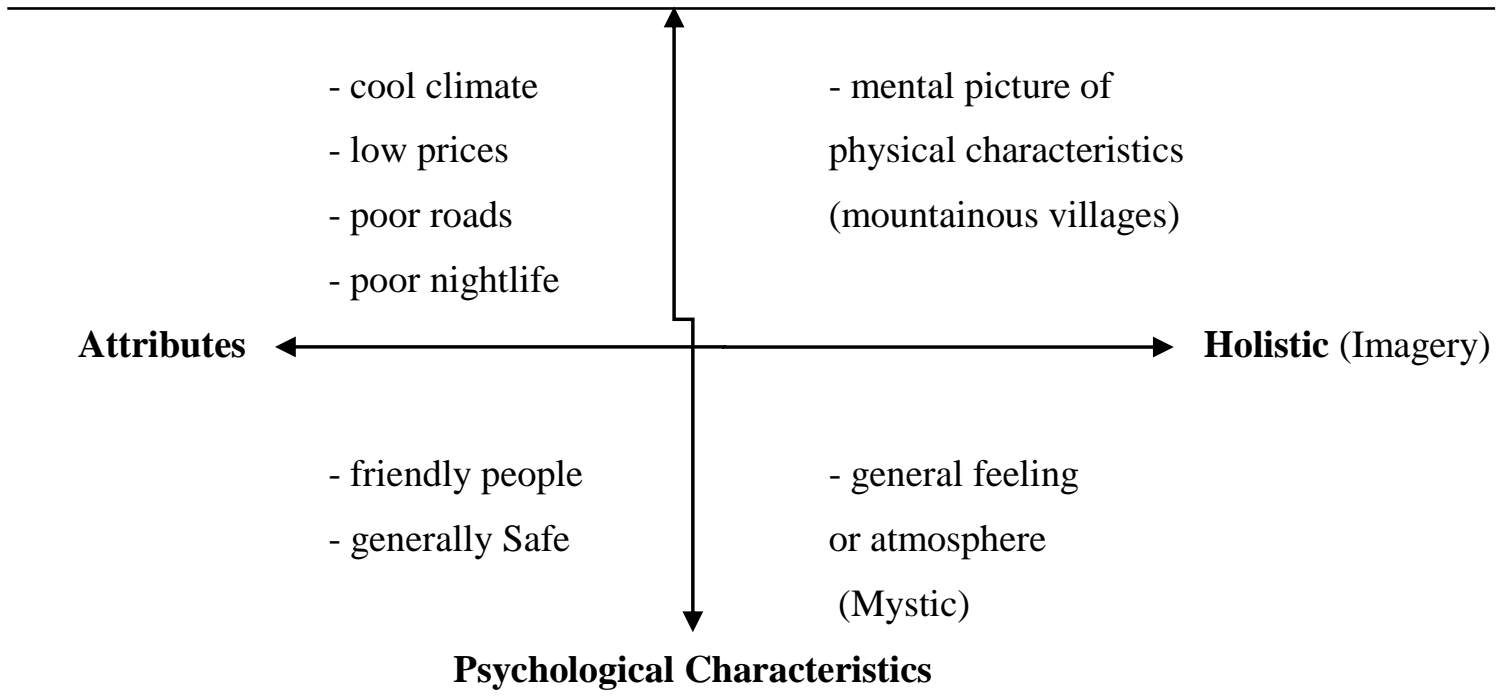

Figure 4. Four components of destination image of Nepal_(Etchner \& Ritchie, 2003, p. 43).

The word 'perception' comes from the Latin perception-, percepio, which means receiving, collecting and action of taking possession, apprehension with the mind of sense (Oxford Genuine Dictionary, 2003). In general, tourists make their travel decisions based on perception rather than reality ( Roehl \& Fesenmaier, 1992, pp. 17-26). Murphy (2000) takes perception as an idea to mirror short and simple positive evaluation toward tourist experience based on visual and audio observation and experience from the surrounding environment (Ranjanthran,et.al, 2010, p. 801). Tourism is the first sector to be take into consideration among health, security, relaxation, and hygiene etc. how the tourists perceive the country.

As the objective of this study, the researcher tries to capture the perception of tourists about their image of tourist destination of Nepal.

\section{METHODOLOGY}

The study was based on the descriptive analysis conducted in Kathmandu valley among 13 tourists. It was the pilot study of my PhD thesis. Random sampling technique was used to select the respondents. Perceptual data was collected by using questionnaires survey. Questionnaires were developed in 5 point Likert's scale. Frequency table, mean, cross tab and chi-square test were done to describe the data and find out the association between the variables.

\section{RESULTS}

There were 8 countries' tourists participating in the study. Among them 3 from Argentina, 2 from India, 2 from Spain, 2 from Netherland and 1/1 from Germany, USA, England and Turkey respectively. $61.5 \%$ male followed by $38.5 \%$ female participated. As for the marital status of the respondent, $61.5 \%$ were unmarried followed by $15.4 \%$ married, $15.4 \%$ single and $7.7 \%$ divorced. 
Employment status of respondents shows that $46.2 \%$ were employed followed by $38.5 \%$ that were self-employed, $7.7 \%$ unemployed and $7.7 \%$ were students. Age of respondents was 22-58. Mean age of respondent was 40 .

Data were collected to identify the perception of tourists about the tourist destination. Tourists were asked about the behaviour of staff of tourist destination. $46.2 \%$ were strongly agreed followed by $38.5 \%$ that reported agree and $15.4 \%$ were gave a neutral answer about the behaviour of the staff of the tourist destination (Table 1).

\begin{tabular}{|c|c|c|c|c|c|}
\hline & & & Sex of & ndents & \\
\hline & & & Male & Female & Total \\
\hline \multirow{6}{*}{$\begin{array}{l}\text { The staff at this tourist } \\
\text { destination is friendly towards } \\
\text { the guests }\end{array}$} & \multirow{2}{*}{ Strongly Agree } & Count & 3 & 3 & 6 \\
\hline & & $\%$ of Total & $23.1 \%$ & $23.1 \%$ & $46.2 \%$ \\
\hline & \multirow{2}{*}{ Agree } & Count & 4 & 1 & 5 \\
\hline & & $\%$ of Total & $30.8 \%$ & $7.7 \%$ & $38.5 \%$ \\
\hline & \multirow{2}{*}{ Neutral } & Count & 1 & 1 & 2 \\
\hline & & $\%$ of Total & $7.7 \%$ & $7.7 \%$ & $15.4 \%$ \\
\hline \multirow{2}{*}{\multicolumn{2}{|c|}{ Total }} & Count & 8 & 5 & 13 \\
\hline & & $\%$ of Total & $61.5 \%$ & $38.5 \%$ & $100.0 \%$ \\
\hline \multicolumn{6}{|l|}{ Chi-Square Tests } \\
\hline & & Value & df & \multicolumn{2}{|c|}{ Asymp. Sig. (2-sided) } \\
\hline Pearson Chi-Square & & $1.170^{\mathrm{a}}$ & 2 & \multicolumn{2}{|c|}{.557} \\
\hline
\end{tabular}

Sources: Pilot study, 2014

There was no significant association $(\mathrm{p}=.557)$ found between the perception of male and female on behaviour about staff at tourist destination.

Respondents were asked about the unique image of tourist destination. $69.2 \%$ strongly agreed followed by $23.1 \%$ who agreed that the tourist destination had unique image whereas $7.7 \%$ had neutral answer (Table 2).

\begin{tabular}{|c|c|c|c|c|c|}
\hline & & & \multicolumn{2}{|c|}{ Sex of respondents } & \multirow{2}{*}{ Total } \\
\hline & & & Male & Female & \\
\hline \multirow{6}{*}{$\begin{array}{l}\text { This tourist destination has a } \\
\text { unique image }\end{array}$} & \multirow{2}{*}{ Strongly Agree } & Count & 6 & 3 & 9 \\
\hline & & $\%$ of Total & $46.2 \%$ & $23.1 \%$ & $69.2 \%$ \\
\hline & \multirow{2}{*}{ Agree } & Count & 2 & 1 & 3 \\
\hline & & $\%$ of Total & $15.4 \%$ & $7.7 \%$ & $23.1 \%$ \\
\hline & \multirow{2}{*}{ Neutral } & Count & 0 & 1 & 1 \\
\hline & & $\%$ of Total & $0.0 \%$ & $7.7 \%$ & $7.7 \%$ \\
\hline \multirow{2}{*}{\multicolumn{2}{|c|}{ Total }} & Count & 8 & 5 & 13 \\
\hline & & $\%$ of Total & $61.5 \%$ & $38.5 \%$ & $100.0 \%$ \\
\hline \multicolumn{6}{|l|}{ Chi-Square Tests } \\
\hline & & Value & $\mathrm{df}$ & \multicolumn{2}{|c|}{ Asymp. Sig. (2-sided) } \\
\hline \multicolumn{2}{|l|}{ Pearson Chi-Square } & $1.593^{\mathrm{a}}$ & 2 & \multicolumn{2}{|c|}{.451} \\
\hline
\end{tabular}

Sources: Pilot study, 2014

There was no significant association $(\mathrm{p}=.451)$ found between the perception of male and female on unique image of tourist destination. 
$46.2 \%$ respondents strongly agreed followed by $38.5 \%$ who agreed that there was good safety and security of tourists at the tourist destination. $15.4 \%$ were found neutral (Table 3 ).

\begin{tabular}{|c|c|c|c|c|c|}
\hline & & & \multicolumn{2}{|c|}{ Sex of respondents } & \multirow{2}{*}{ Total } \\
\hline & & & Male & Female & \\
\hline \multirow{6}{*}{$\begin{array}{l}\text { In this tourist destination, } \\
\text { personal safety and security is } \\
\text { good }\end{array}$} & \multirow{2}{*}{ Strongly Agree } & Count & 3 & 3 & 6 \\
\hline & & $\%$ of Total & $23.1 \%$ & $23.1 \%$ & $46.2 \%$ \\
\hline & \multirow{2}{*}{ Agree } & Count & 3 & 2 & 5 \\
\hline & & $\%$ of Total & $23.1 \%$ & $15.4 \%$ & $38.5 \%$ \\
\hline & \multirow{2}{*}{ Neutral } & Count & 2 & 0 & 2 \\
\hline & & $\%$ of Total & $15.4 \%$ & $0.0 \%$ & $15.4 \%$ \\
\hline \multirow{2}{*}{\multicolumn{2}{|c|}{ Total }} & Count & 8 & 5 & 13 \\
\hline & & $\%$ of Total & $61.5 \%$ & $38.5 \%$ & $100.0 \%$ \\
\hline \multicolumn{6}{|l|}{ Chi-Square Tests } \\
\hline & & Value & $\mathrm{df}$ & \multicolumn{2}{|c|}{ Asymp. Sig. (2-sided) } \\
\hline Pearson Chi-Square & & $1.593^{\mathrm{a}}$ & 2 & \multicolumn{2}{|c|}{.451} \\
\hline
\end{tabular}

Sources: Pilot study, 2014

There was no significant association $(\mathrm{p}=.451)$ found between the perception of male and female on safety and security of tourist in tourist destination.

Tourists were asked about the behaviour of the tourist police with tourists. $53.8 \%$ agreed followed by $15.4 \%$ strongly agreed that the behaviour of tourist police was helpful for tourists. The answer of $30.8 \%$ was neutral (Table 4$)$.

\begin{tabular}{|c|c|c|c|c|c|}
\hline & & & \multicolumn{2}{|c|}{ Sex of respondents } & \multirow{2}{*}{ Total } \\
\hline & & & Male & Female & \\
\hline \multirow{6}{*}{$\begin{array}{l}\text { Behaviour of tourist police is } \\
\text { helpful }\end{array}$} & \multirow{2}{*}{ Strongly Agree } & Count & 2 & 0 & 2 \\
\hline & & $\%$ of Total & $15.4 \%$ & $0.0 \%$ & $15.4 \%$ \\
\hline & \multirow{2}{*}{ Agree } & Count & 3 & 4 & 7 \\
\hline & & $\%$ of Total & $23.1 \%$ & $30.8 \%$ & $53.8 \%$ \\
\hline & \multirow{2}{*}{ Neutral } & Count & 3 & 1 & 4 \\
\hline & & $\%$ of Total & $23.1 \%$ & $7.7 \%$ & $30.8 \%$ \\
\hline \multirow{2}{*}{\multicolumn{2}{|c|}{ Total }} & Count & 8 & 5 & 13 \\
\hline & & $\%$ of Total & $61.5 \%$ & $38.5 \%$ & $100.0 \%$ \\
\hline \multicolumn{6}{|l|}{ Chi-Square Tests } \\
\hline & & Value & $\mathrm{df}$ & \multicolumn{2}{|c|}{ Asymp. Sig. (2-sided) } \\
\hline Pearson Chi-Square & & $2.588^{\mathrm{a}}$ & 2 & \multicolumn{2}{|c|}{.274} \\
\hline
\end{tabular}

Sources: Pilot study, 2014

There was no significant association $(\mathrm{p}=.274)$ found between the perception of male and female about the behaviour of the tourist police at the tourist destination. 
About the availability of tourist police at the tourist destination, sked among the tourists reported that $23.1 \%$ strongly agreed followed by $23.1 \%$ agreed on the anytime availability of tourist police in tourist destination. $38.5 \%$ were found in neutral answer and $15.4 \%$ were disagreed (Table 5).

\begin{tabular}{|c|c|c|c|c|c|}
\hline & & & \multicolumn{2}{|c|}{ Sex of respondents } & \multirow{3}{*}{$\begin{array}{c}\text { Total } \\
3\end{array}$} \\
\hline & & & Male & Female & \\
\hline \multirow{10}{*}{$\begin{array}{l}\text { Anytime tourist polices are } \\
\text { available in tourist destination }\end{array}$} & \multirow{2}{*}{ Strongly Agree } & Count & 2 & 1 & \\
\hline & & $\%$ of Total & $15.4 \%$ & $7.7 \%$ & $23.1 \%$ \\
\hline & \multirow{2}{*}{ Agree } & Count & 2 & 1 & 3 \\
\hline & & $\%$ of Total & $15.4 \%$ & $7.7 \%$ & $23.1 \%$ \\
\hline & \multirow{2}{*}{ Neutral } & Count & 3 & 2 & 5 \\
\hline & & $\%$ of Total & $23.1 \%$ & $15.4 \%$ & $38.5 \%$ \\
\hline & \multirow{2}{*}{ Disagree } & Count & 1 & 0 & 1 \\
\hline & & $\%$ of Total & $7.7 \%$ & $0.0 \%$ & $7.7 \%$ \\
\hline & \multirow{2}{*}{ Strongly Disagree } & Count & 0 & 1 & 1 \\
\hline & & $\%$ of Total & $0.0 \%$ & $7.7 \%$ & $7.7 \%$ \\
\hline \multirow{2}{*}{\multicolumn{2}{|c|}{ Total }} & Count & 8 & 5 & 13 \\
\hline & & $\%$ of Total & $61.5 \%$ & $38.5 \%$ & $100.0 \%$ \\
\hline \multicolumn{6}{|l|}{ Chi-Square Tests } \\
\hline & & Value & df & \multicolumn{2}{|c|}{ Asymp. Sig. (2-sided) } \\
\hline Pearson Chi-Square & & $2.297^{\mathrm{a}}$ & 4 & \multicolumn{2}{|c|}{.681} \\
\hline
\end{tabular}

Sources: Pilot study, 2014

There was no significant association $(\mathrm{p}=.681)$ found between the perception of male and female on availability of tourist police in tourist destination.

Tourist police are assigned for the promotion of safe tourism. $30.8 \%$ respondents were strongly agreed followed by $23.1 \%$ agreed that role of tourist police is effective in promoting the safe tourism. Majority of respondents (46.2\%) were found neutral in their answer (Table 6).

\begin{tabular}{|c|c|c|c|c|c|}
\hline \multicolumn{6}{|c|}{ Table 6. Effectiveness of tourist police in promoting safe tourism } \\
\hline & & & \multicolumn{2}{|c|}{ Sex of respondents } & \multirow{3}{*}{$\begin{array}{c}\text { Total } \\
4\end{array}$} \\
\hline & & & Male & Female & \\
\hline \multirow{6}{*}{$\begin{array}{l}\text { Role of tourist police is } \\
\text { effective in promoting safe } \\
\text { tourism }\end{array}$} & \multirow{2}{*}{ Strongly Agree } & Count & 4 & 0 & \\
\hline & & $\%$ of Total & $30.8 \%$ & $0.0 \%$ & $30.8 \%$ \\
\hline & \multirow{2}{*}{ Agree } & Count & 1 & 2 & 3 \\
\hline & & $\%$ of Total & $7.7 \%$ & $15.4 \%$ & $23.1 \%$ \\
\hline & \multirow{2}{*}{ Neutral } & Count & 3 & 3 & 6 \\
\hline & & $\%$ of Total & $23.1 \%$ & $23.1 \%$ & $46.2 \%$ \\
\hline \multirow{2}{*}{\multicolumn{2}{|c|}{ Total }} & Count & 8 & 5 & 13 \\
\hline & & $\%$ of Total & $61.5 \%$ & $38.5 \%$ & $100.0 \%$ \\
\hline \multicolumn{6}{|l|}{ Chi-Square Tests } \\
\hline & & Value & $\mathrm{df}$ & \multicolumn{2}{|c|}{ Asymp. Sig. (2-sided) } \\
\hline Pearson Chi-Square & & $3.846^{\mathrm{a}}$ & 2 & \multicolumn{2}{|c|}{.146} \\
\hline
\end{tabular}

Sources: Pilot study, 2014 
There was no significant association $(\mathrm{p}=.146)$ found between the perception of male and female on effectiveness of tourist police in promoting safe tourism in the tourist destination.

Regarding the cleanliness of environment of tourist destination, 38.5\% agreed followed by $30.8 \%$ strongly agreed that overall cleanliness of the destination was good. Similarly, $23.1 \%$ respondents were found in neutral position in their answer and $7.7 \%$ disagreed about the cleanliness of the tourist destination (Table 7).

\begin{tabular}{|c|c|c|c|c|c|}
\hline & & & Sex of & ondents & \\
\hline & & & Male & Female & \\
\hline \multirow{8}{*}{$\begin{array}{l}\text { Overall cleanliness of the } \\
\text { destination is good }\end{array}$} & \multirow{2}{*}{ Strongly Agree } & Count & 2 & 2 & 4 \\
\hline & & $\%$ of Total & $15.4 \%$ & $15.4 \%$ & $30.8 \%$ \\
\hline & \multirow{2}{*}{ Agree } & Count & 4 & 1 & 5 \\
\hline & & $\%$ of Total & $30.8 \%$ & $7.7 \%$ & $38.5 \%$ \\
\hline & \multirow{2}{*}{ Neutral } & Count & 1 & 2 & 3 \\
\hline & & $\%$ of Total & $7.7 \%$ & $15.4 \%$ & $23.1 \%$ \\
\hline & \multirow{2}{*}{ Disagree } & Count & 1 & 0 & 1 \\
\hline & & $\%$ of Total & $7.7 \%$ & $0.0 \%$ & $7.7 \%$ \\
\hline \multirow{2}{*}{\multicolumn{2}{|c|}{ Total }} & Count & 8 & 5 & 13 \\
\hline & & $\%$ of Total & $61.5 \%$ & $38.5 \%$ & $100.0 \%$ \\
\hline \multicolumn{6}{|l|}{ Chi-Square Tests } \\
\hline \multirow{2}{*}{\multicolumn{2}{|c|}{ Pearson Chi-Square }} & Value & $\mathrm{df}$ & \multicolumn{2}{|c|}{ Asymp. Sig. (2-sided) } \\
\hline & & $2.578^{\mathrm{a}}$ & 3 & \multicolumn{2}{|c|}{.461} \\
\hline
\end{tabular}

Sources: Pilot study, 2014

There was no significant association $(\mathrm{p}=.461)$ found between the perception of male and female on overall cleanliness of tourist destination.

\section{DISCUSSIONS}

The previous study shows that by the 1970s, foreign tourists' interest in Nepal had shifted from hippie to yuppie, from experience to adventure, turning the country into consumable destination to be bought and sold (Norum, 2013, p. 43). There are many factors which influence the tourists about where to go on holiday and one of these factors is the safety or perceived safety of the destination. The perception of safety, both personal safety and safety of the venue, is vital to the success of a tourist destination. Risk perception and feeling of safety during travel appear to have stronger influence on avoidance of regions than likelihood of travel to them (Azim, 2010, p. 28). If a tourist feels unsafe or threatened at a holiday destination, he or she can develop a negative impression of the destination. In contrast, if the destinations do not pose any harm, either physically or mentally, to tourists, they can enjoy the destination offerings and return home safely (Sungsoo, 2003, p. 14). In relation to the safety and security of tourists in Nepal, around $85 \%$ tourists felt safe at the tourist destinations of Nepal, which supports the positive image of Nepal as a tourist destination.

Crimes against tourists can be classified into two broad categories: crime of opportunity such as robbery, assault and rape; and planned crime such as terrorism (M. H. Flicker \& Gardner, 2002). When customers feel that such risks are too high, they change their plan or behaviour, such as nonbooking, cancellation, or evacuation from the perceived risk destinations (Sasso, 2005, p. 465). In my findings also, tourists reported some incidents like robbery, cheating from Taxi drivers and hotels. Such types of minor accidents can also be barriers to the efforts to increase the numbers of tourists and build the negative image of the tourist destination. 
The image of the tourist destination itself represents tourist's tendency to choose or reject a given destination and also the attitude that tourist develops toward destinations, which ultimately matters in decision making (Lopes, 2011, p. 311). Hunt demonstrates the importance of the "destination image" for increasing the number of tourists visiting destination as much as, or even more than, tangible resources.

Regarding the tourist's satisfaction with role of the tourist police, more than $50 \%$ tourist reported agreed about the effectiveness of the tourist police for the promotion of safe tourism in my study. Tourist satisfaction is widely accepted as being of central importance to destination the management of the destination. A totality of impressions, beliefs, ideals, expectations and feelings accumulated towards a place over time (Kim H. \& Richardson 2003, p. 218). Therefore inadequate security measures in place for visitors are considered to be a central obstacle hindering the growth of a healthy tourism industry in many destinations (Lockwood \& Medlik, 2002, p. 147).

According to Hunter-Jones argues "Although there are many reasons for a successful tourism product, such as the quality of service, a good time, beautiful scenery, and/ or interesting encounters, all these factors require a safe and secure destination "(Qtd. in Pimmda \& Nuntiya, 2012, p. 1372). Regarding the other factors of the tourist destination to attract the tourists, they were asked about their perception of the cleanliness of tourist destination. Around $70 \%$ tourists found satisfied with the cleanliness of the tourist destinations of Nepal.

Tourists do not want to visit places where they do not feel safe or feel threatened. It is, therefore, important for tourism industry to ensure the safety of tourists.

In recent times, the Government of Nepal realized the importance of tourism in its economic and social life. Therefore, the government decided to combine both the government and the private sectors into one organization as Nepal Tourism Board, established on 1988 for better coordination, promotion, development and marketing of tourism industry in order to develop Nepal as an attractive tourist destination. Tourist police was established on Jan 26, 1979 under the Ministry of Tourism and Civil Aviation with the motto of "friendly, fast and right". Tourist police assures a safe and pleasant stay to the entire tourists during their stay in Nepal.

\section{CONCLUSION}

Tourism is the fastest growing industry of the world and considered as world's larger export earner and very important factor in the balance of payment. In Nepalese context, tourism industry has significant impact on foreign exchange, employment opportunities and economic development. Perception about tourists on tourist destinations was collected from the questionnaire survey. They were asked about the behaviour of staff at the tourist destination, unique image of tourist destination, personal safety and security of tourists, behaviour of tourist police, and availability of the tourist police at the tourist destinations, effectiveness of tourist police in promotion of safe tourism and the overall of cleanliness of tourist destination. There was no significant association found $\mathrm{i}$ the perception of gender regarding the tourist destination.

\section{ACKNOWLEDGEMENT}

I am indebted to my respected supervisor, Dr. Mr. Tek Nath Dhakal, Head of Public Administration Department, TU, Kathmandu, for his remarkable guidance during my research work. In addition, I must acknowledge the support I received from Centre for Excellence for PhD Studies and also thankful to the Mewar university, Rajasthan, India. 


\section{BIBLIOGRAPHY}

Etchner C. M. \& Ritchie B. (Vol. 14, No. 1, 2003). The meaning and measurement of destination Image. The Journal of Tourism Studies , 43.

Roehl W. S. and Fesenmaier D. R. (1992). Risk perceptions and pleasure travel: An exploratory analysis. Journal of Travel Research, 17-26.

Azim, T. S. (Vol. 5, No. 2, 2010). The relationship between perception of risk and decision making process of travel of french tourists: The case of Egypt. tourismos: An International Multidisciplinery journal of Tourism , 28.

Baker D. \& Crompton J. (Vol. 27, No. 3, 2000). Quality, Satisfaction and Behavioural intentions. Annals of Tourism Research, 785-804.

Beirman, D. (2003). Restoring tourism destination in crisis. A strategy marketing approach. Wallingford, uk: CAB International.

Blsuglu S. \& McCleary K. W. (Vol. 35, No. 4, 1999a). A Model of destination image formation . Annals of Tourism Resrearch, 11-15.

Charlotte Etchner \& J. R. Brent Ritchie. (Vol. 14, No. 1, 2003). meaning and measurement of destination Image. The Journal of Tourism Studies , 42.

Crompton, J. (Vol.17, 1979). An assessment of the image of the mexico as a vacation destination and the influence of geographical location upon that image. Journal of Travel Research, 18-43.

Gunn, C. A. (1972). Vacationscape-Designing Tourist Regions. Austin, Texas: University of Texas.

Henkinson, G. (Vol.13, No.1, 2004). The brand image of Tourism destination: A study of saliency organic images. Journal of product and Brand Management , 6-14.

Hudman, L. (1980). Tourism: shrinking world. Columbus, Ohio: OH: Grid publication.

Hunt, J. D. (Vol. 13, No. 3, 1975). Image as a factor in tourism development. Journal of Travel Research, 1-17.

Kassean Hemant \& Gassita Rhaaita. (Vol. 2, No. 3, 2013). Exploing tourist push and pull motivations to visit Muritusus as a tourist destination. African Journal of Hospitality, Tourism and Leisure, 2.

Kim H. \& Richardson S. L. (Vol. 30, N0. 1, 2003). Motion pictures impact on destination image. Journal of Tourism Research, 218.

kuscer, k. (2012). Modelling mountain tourism destination development with focus on inovativeness. Ljubljana: University of Ljubljana.

Lawson F. \& Baud bovy M. (1977). Tourism and Recreational development. London: Architectectural Press.

Lockwood A. \& Medlik S. (2002). Tourism and Hospitality in the 21st century. Oxford: Butterworth Heinemann.

Lopes, S. D. (Vol. 9, No. 2, 2011). Destination image: Origin, Development and Implication. PASOS , 311.

M. H. Flicker \& M. P. Gardner. (2002). Which is scarier: The mall of mail ? Direct marketing education foundation Annual conference. Sanfrancisco, CA: Direct marketing education foundation.

Norum, R. E. (Vol. 3, No. 1, 2013). The unbearable likeness being a tourist: Expats, Travel and Imaginaries in the neo colonial Orient. International Review of Social Research , 43.

Omerzel, D. G. (Vol.17, No.1, 2011). Stakeholders' understanding of factors influencing tourism demand conditions: The case of Slovania. Tourism and Hospitality management , 6.

Pearce, P. L. (1988). The ulysses factor. New York: Springer Verlag. 
R. H. Garcia, M. L. (31 july, 2012). Conjoint analysis of tourist choice of hotel attributes presented in travel agent Brochures. International Journal of Tourism Research , 65.

Rahaman, M. S. (Vol. 7, No.1, 2012). Exploring Tourists' Perception: The case of Bangladesh. Tourismos: An International Multidisciplinery journal of Tourism, 84.

Rajesh, R. (Vol. 11, No. 3, 2013). Impact of tourist Perception, Destinaiton image and tourist satisfaction on destination loyalty: A conceptual model. PASOS , 68.

Rajesh, R. (Vol. 11, No. 3, 2013). Impacts of tourist perceptions, destination image and tourist satisfaction on destination loyalty: Conceptual model. Revista de Turismo y Patrimonio Cultural , 68.

Ranjanthran Mageswari, Mohammad baduruddin and Malaysia Sains. (2010). Domestic Tourism: Perception of domestic tourist on touris products in penang island. Asian Journal of Management Research, 801.

Sasso, S. (2005). International encyclopedia of hospitality management. Burlington: Elsevier, Butterworth-Heinemann.

Sungsoo, P. (Vol. 1, No. 1, 2003). Perspectives of tourist safety dimension research. Review of Tourism Research, 14.

Tasci A. D. \& Gartner W. A. (Vol. No. 45, No. 4, 2007). Destination image and its functional relationships. Journal of Travel Researh , 413-425.

Wichasin Pimmda \& Doungphummes Nuntiya. (2012). Acomparative study of International tourists' safety needs and Thai tourist police' perception towards international tourists' safety needs. World Academy of Science, Engineering and Technology, 1372.

Woodside A. \& Martin D. (2008). Tourism management: Analysis, Behiviour and Strategy. Oxford, UK: Cabi International.

WTO. (1995). Concept, definition and classifications for tourism statistics. Technical manual, 1. 